\title{
Growth and development of mangrove forests overlying smothered coral reefs, Sulawesi and Sumatra, Indonesia
}

\author{
Daniel M. Alongi ${ }^{1, *}$, Lindsay A. Trott ${ }^{1}$, Rachmansyah ${ }^{2}$, Frank Tirendi ${ }^{1}$, \\ A. David McKinnon ${ }^{1}$, Mohammed C. Undu ${ }^{2}$ \\ ${ }^{1}$ Australian Institute of Marine Science, PMB 3, Townsville MC, Queensland 4810, Australia \\ ${ }^{2}$ Research Institute for Coastal Aquaculture, Jl. Makmur Dg. Sitakka, Maros, Sulawesi Selatan, Indonesia
}

\begin{abstract}
Smothering of many fringing coral reefs in Indonesia has led to mangrove colonization of the overlying soils in a process of human-induced succession. On the islands of Sulawesi and Sumatra, we measured some structural and functional attributes of 4 mangrove forests that have colonized such soil drapes. The forests varied extensively in stem density, above-ground biomass, and in leaf area index. We estimated accumulation rates of above-ground forest biomass of 1.5 to $8.1 \mathrm{t} \mathrm{C} \mathrm{ha}^{-1} \mathrm{yr}^{-1}$, similar to other mangroves. The ratio of greenhouse $\mathrm{C}$ and $\mathrm{N}$ emissions from soils averaged 35 compared with an average soil C:N ratio of 38. Soil ammonification was sufficient to meet forest $\mathrm{N}$ demand. A value of 1 to $4 \%$ of soil C metabolism was involved in dissolving carbonate, with sulfate reduction being the major decomposition pathway. Rapid rates of $\mathrm{N}_{2}$ loss were measured, but there was no detectable $\mathrm{N}_{2} \mathrm{O}$ release. Rates of nitrogen fixation on the soil surface ranged from 97 to $1648 \mu \mathrm{mol} \mathrm{N} \mathrm{m}{ }^{-2} \mathrm{~d}^{-1}$, but higher rates (860 to $4316 \mu \mathrm{mol} \mathrm{N} \mathrm{m}{ }^{-2} \mathrm{~d}^{-1}$ ) were measured on microbial mats covering pneumatophores, suggesting $\mathrm{N}_{2}$ fixation on above-ground tree parts may balance soil $\mathrm{N}_{2}$ losses. Rates of forest biomass accumulation related exponentially to rates of soil C and $\mathrm{N}$ metabolism, reflecting a close relationship between tree growth and nutrient availability as mediated by microbes in these shallow soils. These patterns are similar to those in other mangrove forests, and illustrate that human-induced change has resulted in a clear shift from reef-dominated to mangrovedominated habitats and functional characteristics in parts of coastal Indonesia.
\end{abstract}

KEY WORDS: Carbon · Greenhouse gases · Mangrove $\cdot$ Nitrogen $\cdot$ Indonesia

\section{INTRODUCTION}

Mangrove forests are often found in close proximity to coral reefs and reef-associated habitats in tropical seas. In coastal cays and lagoons, mangroves often grow on unconsolidated reef sediments and coral terraces that have risen above mean sea level (Woodroffe 2002, Bird 2008). Mangrove forests can also facilitate seaward development of coral reefs by maintaining water clarity and by enhancing deposition of fine particles. Thus, the development of mangrove forests is often intertwined with the environmental history of coral reefs, and vice versa. Such interrelationships are most evident where degradation of the coastal environment is accelerating, such as throughout Southeast
Asia. In Indonesia, as in other regional countries, increased deforestation and coastal development has led to enhanced land erosion and subsequent transport of catchment soils to the coastal zone (Minura 2006); sedimentation has increased since the 1970 s to the extent that fringing reefs are disappearing, leading to colonization of the recently deposited soil drapes by mangroves and seagrass beds (Budiman et al. 1986, Yulianto et al. 2004, Alongi et al. 2008, Sekiguchi \& Aksornkoae 2008).

Coastal degradation has led to a severe decline in the distribution and health of coral reefs along Indonesian shores (Rice 1991, Tomascik et al. 1997). Recent studies indicate that $6 \%$ of Indonesia's reefs are in excellent condition, but the remainder are in various 
stages of degradation (Nontji 2000, Tun et al. 2004, Sekiguchi \& Aksornkoae 2008). Indonesia also houses the world's largest expanse of mangrove forest ( 2 930000 ha), but has experienced an inexorable decline in forest area (FAO 2003). Mangroves, however, are adaptable and resilient to dynamic shoreline change caused by increased sedimentation due to changes in land use (Alongi 2008); mangroves have undergone almost continual disturbance as a result of fluctuations in sea level over the last few thousand years (Woodroffe 2002, Bird 2008). In the face of environmental change, mangroves shift their shoreline position, readily colonizing newly deposited sediments. Although the colonization of soil drapes by mangroves has been documented in Indonesia (Budiman et al. 1986, Sekiguchi \& Aksornkoae 2008), the structural and functional characteristics of these forests are unknown.

A study was conducted on 4 such reef-associated mangroves on Sumatra and Sulawesi in Indonesia to answer the following questions: (1) What is the species composition, above-ground biomass, and leaf-area index of these forests? (2) What are the rates of forest biomass accumulation as estimated from the date of initial smothering and subsequent colonization? (3) Do estimated rates of forest growth relate to rates of soil metabolism and nutrient availability?
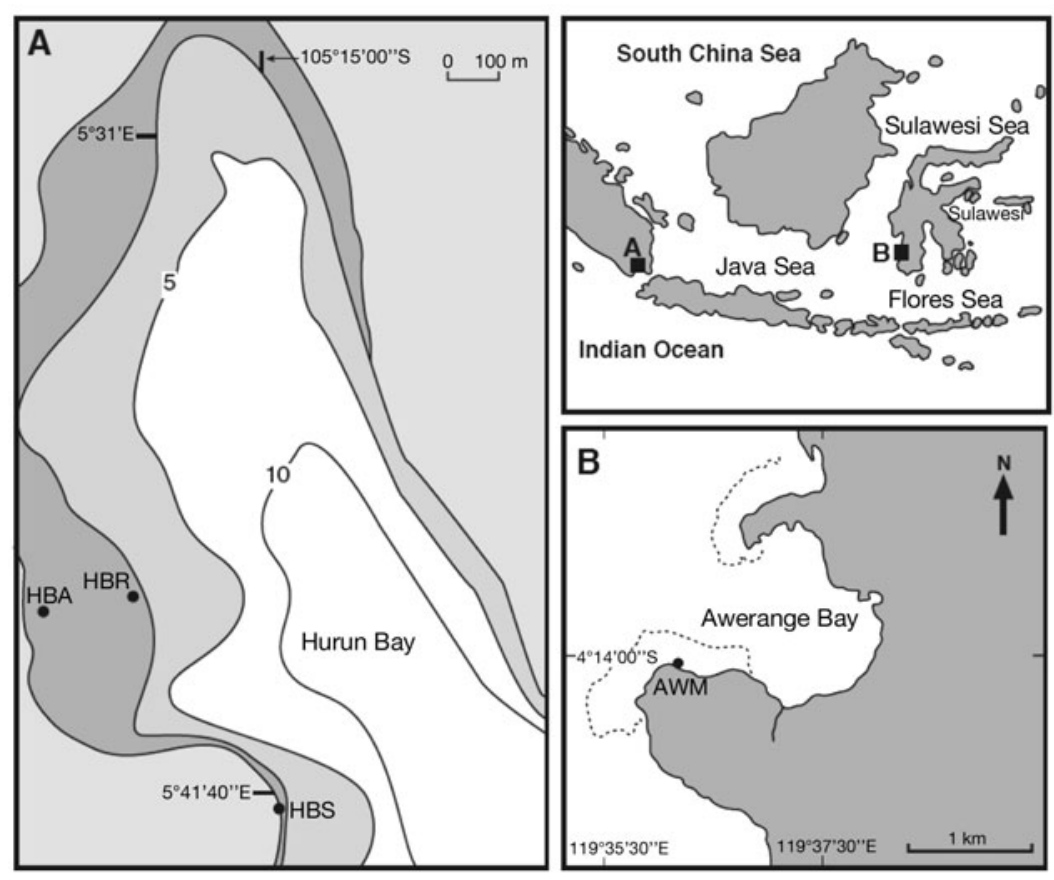

Fig. 1. Chart showing (A) the location of 3 mangrove forests (Stns HBA, HBR, HBS) in Hurun Bay in the Gulf of Lampung, southeastern Sumatra, (B) 1 mangrove forest (Stn AWM) in Awerange Bay along the southwestern coast of Sulawesi, Indonesia, and (C) an overview of the area. Light gray area in (A) is mudflat and dark gray area is mangrove forest

\section{MATERIALS AND METHODS}

Study sites. The study was conducted during the dry season (August 2006) and wet season (March 2007) in Hurun Bay on the island of Sumatra and in Awerange Bay on the island of Sulawesi, Indonesia. Hurun Bay is located in Lampung Regency on the northwest coast of the Gulf of Lampung in southern Sumatra (Fig. 1A). The bay is horseshoe shaped and $1.5 \mathrm{~km}^{2}$ in area with a $1.8 \mathrm{~m}$ tidal range. Mean depth is $12 \mathrm{~m}$, but the bay is lined with extensive mudflats and mangroves that overlie coral reefs smothered by runoff accelerated by catchment erosion beginning in the $1970 \mathrm{~s}$; under the most landward mangroves lies coral rock, which is a remnant of coral terraces found throughout southern Sumatra (Whitten et al. 2000). Live coral persists at the seaward edge of the bay. The climate in this area is seasonal, with a July to September dry season; annual rainfall ranges from 1500 to $2500 \mathrm{~mm}$ (Whitten et al. 2000, Chuan 2005). Three mangrove forests were sampled in Hurun Bay (Fig. 1A). Stn HBA was a highintertidal forest colonized mainly by Avicennia marina with A. officinalis and Rhizophora stylosa as canopy sub-dominants. Stn HBR was a forest located in the mid-intertidal zone composed of $R$. stylosa; both Stns HBA and HBR occupied the same soil drape over smothered reefs. Stn HBS was a low-intertidal forest situated on a dead fringing reef and consisting of $R$. stylosa with $R$. apiculata as a sub-dominant.

Awerange Bay is located in Barru Regency, South Sulawesi Province, on the southwest coast of the island of Sulawesi (Fig. 1B). The bay is crescent shaped and $5.4 \mathrm{~km}^{2}$ in area, with a $1.2 \mathrm{~m}$ tidal range and mean depth of $14 \mathrm{~m}$ and fringing coral reefs occupying most of the bay entrance and mangroves and seagrass beds inhabiting most of the southern end of the bay. Degraded coral reefs lie beneath a thin veneer of mangrove soil and trees along the southern coast of the bay. Stn AWM was a low-intertidal forest (Fig. 1B) colonized by Sonneratia caseolaris and S. lanceolata with Lumnitzera racemosa as a sub-domininant. The climate in this area is seasonal, with the wettest months from December to May and annual rainfall ranging from 2000 to $3000 \mathrm{~mm}$ (Whitten et al. 1987, Chuan 2005).

According to senior staff at Balai Bududaya Laut (BBL) in Lampung (Dr. Sudjiharno, Mr. Hartwono), the coral 
reefs of Hurun Bay started dying in the late-1970s due to eutrophication from adjacent aquaculture ponds, but it was not until massive sheet erosion occurred during the wet season of 1977 that these reefs were smothered; mangrove seedlings subsequently appeared in early 1978. At Stn HBS, at the edge of the bay, the reefs were not smothered, but died in 1974 due to eutrophication from effluent from the BBL laboratory, and it was during that year that seedlings first appeared. Likewise, in Awarange Bay on Sulawesi, the fringing reefs died as a result of runoff from aquaculture effluent, with subsequent establishment of mangroves beginning in 1981 (Dr. Taufik Ahmed, Research Institute for Aquaculture, Maros).

Forest structure, biomass, and leaf area index. Forest measurements were made in 2006. Within each forest, 3 separate sets of measurements were made for species identification, basal area, and diameter at breast height $(\mathrm{DBH})$ using the angle count cruising method (Cintron \& Novelli 1984, Clough 1997). These data were used to calculate stem density, which, in turn, was used to estimate above-ground biomass using the allometric relationships for each species in Clough \& Scott (1989) and Clough et al. (1997).

Within these same plots, measurements of light absorption by the forest canopy (100 to 250 light readings per plot on sunny days between 10:00 and 14:00 h) were taken to estimate canopy cover and leaf area index (LAI) using the formula:

$$
\text { LAI }=\left[\log _{\mathrm{e}}(I)_{\text {mean }}\right]-\left[\log _{\mathrm{e}}\left(I_{0}\right)_{\text {mean }}\right] /-k
$$

where $(I)_{\text {mean }}$ is the mean photosynthetically active radiation (PAR) under the canopy, $\left(I_{0}\right)_{\text {mean }}$ is incident PAR, and $k$ is the canopy light extinction coefficient (0.5). LAI was corrected to a solar zenith angle $(\theta)$ of $4^{\circ}$ and $5^{\circ}$ latitude for Sulawesi and Sumatra, respectively.

The extent of tidal inundation was assessed at each site using the stake method described in Clough (1997).

Field sampling and soil analysis. Solid-phase elements were measured from cores taken only during the dry season. pH was measured in both seasons. Soil samples were taken within each triplicate plot in each of the 4 forests at low tide using a hand-held, $1.5 \mathrm{~m}$ long, stainless steel corer ( $7 \mathrm{~cm}$ i.d.). pH was measured sequentially immediately after the core was extruded using a calibrated Model PBFC pH electrode connected to a TPS LC 80 meter. Further cores were taken to the depth of maximum penetration at each site. Subsamples were taken at $2 \mathrm{~cm}$ intervals, frozen, and, on return to the laboratory, wet and dry weighed to determine water content. They were then ground to a fine powder for determination of total $\mathrm{C}$ and total $\mathrm{N}$ on a Perkin-Elmer 2400 CHNS/O Series II Analyzer and for total organic carbon on a Shimadzu TOC Analyzer with a solid sampler after gentle acid treatment to remove carbonates. Total $\mathrm{P}, \mathrm{Fe}, \mathrm{Ca}$, and $\mathrm{Mn}$ were determined after strong acid digestion on a Varian Liberty inductively coupled atomic emission spectrometer following procedures of Loring \& Rantala (1992). Total inorganic carbon was assumed to be $\mathrm{CaCO}_{3}$, as determined by the difference between the total carbon (TC) and total organic carbon (TOC) concentrations.

Sulfate reduction. Rates of sulfate reduction were measured from triplicate $2.7 \mathrm{~cm}$ diameter plastic cores taken to the depth of maximum penetration. The cores were capped at both ends and injected at $1 \mathrm{~cm}$ intervals with carrier-free ${ }^{35} \mathrm{SO}_{4}$. The samples were then incubated for 9 to $18 \mathrm{~h}$, and then terminated by fixing soils in $20 \%$ zinc acetate. Samples were then frozen until a 2-step distillation procedure (Fossing \& Jorgensen 1989) was performed to determine the fraction of reduced radiolabel shunted into the acid-volatile sulfide (AVS) and chromium-reducible (CRS) sulfur pools.

Solute fluxes across the soil-water interface. Fluxes of DIC, $\mathrm{Ca}, \mathrm{Fe}, \mathrm{Mn}, \mathrm{H}_{2} \mathrm{~S}$, and $\mathrm{O}_{2}$ across the soil-water interface were measured from 3 opaque chambers (volume $=1 \mathrm{l}$; area $=82 \mathrm{~cm}^{2}$ ) and fluxes of $\mathrm{NH}_{4}{ }^{+}, \mathrm{NO}_{2}{ }^{-}$ $+\mathrm{NO}_{3}{ }^{-}$, and $\mathrm{PO}_{4}{ }^{3-}$ were measured in 3 clear chambers over 4 to $6 \mathrm{~h}$. Samples for solutes were taken hourly. The chambers were incubated under shade cloth in a running seawater bath to maintain ambient seawater temperature. Each chamber had a propeller-electric motor unit and 2 sampling ports on opposite sides of the chamber (Alongi et al. 2006). Dissolved oxygen was measured using an $\mathrm{O}_{2}$ probe (TPS Model WP-82 DO meters) placed into 1 sampling port; the other port was fitted with acid-washed Teflon tubing to draw off $10 \mathrm{ml}$ samples for dissolved inorganic carbon (DIC) and other solutes. The solutes were filtered $(0.45 \mu \mathrm{m}$ Minisart filters) and kept cool and dark (DIC) or frozen (inorganic nutrients) until analysis. Concentrations of dissolved inorganic nutrients were determined using automated techniques (Ryle et al. 1981, Ryle \& Wellington 1982). DIC and $\mathrm{H}_{2} \mathrm{~S}$ were determined using the procedure of Hall \& Aller (1992) to measure DIC and that of Lustwerk \& Burdige (1995) to measure DIC in the presence of $\mathrm{H}_{2} \mathrm{~S}$. The concentration of $\mathrm{H}_{2} \mathrm{~S}$ was estimated by the difference between these 2 values. Dissolved $\mathrm{Ca}, \mathrm{Fe}$, and $\mathrm{Mn}$ were measured on the Varian ICP-MS.

Net $\mathrm{DIC}, \mathrm{Fe}, \mathrm{Mn}$, and $\mathrm{NH}_{4}{ }^{+}$production in soil incubations. Rates of net $\mathrm{DIC}, \mathrm{Fe}, \mathrm{Mn}$, and $\mathrm{NH}_{4}{ }^{+}$production in soil were measured by incubating 2 sets of triplicate soil cores taken at low tide from each plot (Alongi et al. 2006). One set of cores was sliced immediately at $2 \mathrm{~cm}$ intervals and porewater for measurement of $\mathrm{Fe}, \mathrm{Mn}$, and DIC was collected by centrifugation. To the soil samples, 1 to $5 \mathrm{ml}$ (depending on soil volume) of $1 \mathrm{M}$ 
$\mathrm{KCl}$ was added and mixed into each sample. After $2 \mathrm{~h}$, the samples were centrifuged to obtain porewater that was filtered $(0.45 \mu \mathrm{m})$ and placed into sterile plastic test tubes and frozen until measurement of total extractable $\mathrm{NH}_{4}{ }^{+}$. Soil from the other set of cores was mixed, with sub-samples placed in opaque glass bottles that were hermetically sealed and then incubated at in situ temperature for $6 \mathrm{~d}$. After incubation, the samples were processed identically to the other set of cores. After filtration, concentrations of $\mathrm{NH}_{4}{ }^{+}, \mathrm{DIC}, \mathrm{Fe}$, and $\mathrm{Mn}$ were determined as described earlier.

Gas fluxes. Fluxes of $\mathrm{CO}_{2}$ and $\mathrm{O}_{2}$ across the soil-air interface were measured in 3 opaque chambers (identical to those used for solute fluxes) taken from each site at low tide. A stream of airflow was maintained by the propeller unit to minimize gas build up. The chambers were incubated in a shaded water bath maintained at ambient seawater temperature. Water was up to, but not over, the soil surface in each chamber. Gas samples were obtained by extracting gas headspace samples using a syringe and needle via a port fitted with a gastight septum. Gas analyses were carried out on gas chromatographs fitted with TCD detectors (MTI Analytical Instruments P200 fitted with Poraplot Q and Molesieve 5A columns and a Hewlett-Packard M Series Micro GC Model G2890A fitted with Porapak U and Molesieve 5A columns). Certified gas standards were injected at regular intervals for calibrations and confirmation of peak identification. All gas measurements were made every $30 \mathrm{~min}$ for as long as a linear change was detected $(\sim 3 \mathrm{~h})$.

Denitrification (+ potential ammonium oxidation) was measured from replicate soil samples using the $\mathrm{N}_{2}$-gas flux technique (Nowicki 1994). Fluxes of $\mathrm{CO}_{2}$, $\mathrm{CH}_{4}$, and $\mathrm{N}_{2} \mathrm{O}$ were measured in the same chambers. Open-ended bottles were carefully pushed 8 to $10 \mathrm{~cm}$ into the soil (volume $=385 \mathrm{~cm}^{3}$ ), and samples were kept at ambient temperature in an aerated running seawater bath after return to the laboratory. Any obvious surface fauna was removed with forceps before each sample was extruded into a gas-tight glass chamber (height $=23.5 \mathrm{~cm}$; i.d. $=7.6 \mathrm{~cm}$ ). Soils in each chamber were covered with seawater sparged with either $80 \% \mathrm{He} / 20 \% \mathrm{O}_{2}$ mixture (4 experimental chambers per site) or $100 \%$ He (2 or 3 control chambers per site) to remove $\mathrm{N}_{2}$ and, in the case of the experimental cores, to maintain dissolved $\mathrm{O}_{2}$ concentrations. The overlying water in each sealed chamber was stirred continuously. All chambers were incubated for $7 \mathrm{~d}$ in the dark at ambient temperature.

In the experimental chambers, the gas phase was flushed every $8 \mathrm{~h}$ for the first $2 \mathrm{~d}$ with a $80 \% \mathrm{He} / 20 \%$ $\mathrm{O}_{2}$ mixture, and again immediately after the water overlying the soils was replaced on Day 3. The control chambers were treated similarly, but incubated under anoxic conditions (He only in gas flushes and $\mathrm{He}$ purged low $-\mathrm{N}_{2}$ seawater on Day 3) to block nitrification and denitrification. Background de-gassing of $\mathrm{N}_{2}$ in the control chambers was subtracted from the total $\mathrm{N}_{2}$ flux measured in the experimental chambers to derive the rate of $\mathrm{N}_{2}$ flux due to denitrification + possible $\mathrm{NH}_{4}{ }^{+}$ oxidation (Nowicki 1994). $\mathrm{N}_{2}$ flux rates were calculated as the average rate of triplicate cores from each site, from 3 or 4 individual $24 \mathrm{~h}$ incubation periods. $\mathrm{CH}_{4}$, $\mathrm{CO}_{2}$, and $\mathrm{N}_{2} \mathrm{O}$ accumulation rates in the gas headspaces were considered de novo synthesis and were calculated as the average rate of triplicate cores from each station using oxic chambers only.

Nitrogen fixation. Nitrogen fixation in soils from each plot was measured in 3 or 4 opaque and clear chambers using the acetylene reduction technique (Capone 1993). Samples were taken by inserting openended chambers (surface area $=64 \mathrm{~cm}^{2}$ ) into the soil to a depth of $5 \mathrm{~cm}$. The chambers and soil plugs were then gently withdrawn with minimal disturbance. The bases of the chambers were sealed with PVC caps containing an inert rubber plate. A $10 \%$ acetylene/air mixture was created (soil volume $=320 \mathrm{~cm}^{3}$ ), added in the water phase, and the headspace was sampled immediately and at $3 \mathrm{~h}$ intervals, with a final sampling at $20 \mathrm{~h}$. Acetylene and ethylene were analyzed simultaneously by gas chromatography. The ethylene rates were converted to rates of $\mathrm{N}_{2}$ fixation using the theoretical factor of $3 \mathrm{C}_{2} \mathrm{H}_{2}$ molecules equalling $1 \mathrm{~N}$ molecule (Capone 1993).

Statistics. Differences in forest and soil parameters were tested using either 1-way (site), 2-way (site $\times$ depth), or 3-way (site $\times$ depth $\times$ season) ANOVA (Sokal \& Rohlf 1995) followed by Ryan's Q-test (Day \& Quinn 1989) for multiple comparisons when significant main effects were found. Data from replicate plots were pooled if differences among plots were not significant. If necessary, data were square-root transformed. Flux rates were determined by least-squares regression, and relationships among variables were explored using best-fit regression analysis. Results were compared at the $5 \%$ level of significance.

\section{RESULTS}

\section{Forest structure, biomass, and LAI}

The Avicennia marina-dominated forest (Stn HBA) was the most dense and composed of the smallest (by $\mathrm{DBH}$ ) trees (Table 1). Stn HBR was composed of larger, but less dense, Rhizophora stylosa. Both forests had similar canopy cover, LAI, and above-ground biomass. Stn HBS was composed of the largest trees in Hurun Bay with an above-ground biomass of $260 \mathrm{t}$ dry weight 
Table 1. Structural characteristics (mean \pm SE) of the 4 mangrove forests (locations see Fig. 1) on Sumatra and Sulawesi, Indonesia. Data are from triplicate plots per forest. BA: basal area; DBH: diameter at-breast height; AGB: above-ground biomass; LAI: leaf area index; DW: dry weight. Tidal inundation is a percentage of time inundated by tides per month

\begin{tabular}{|lcccccccc|}
\hline Stn & $\begin{array}{c}\text { Forest } \\
\text { age } \\
(\mathrm{yr})\end{array}$ & $\begin{array}{c}\text { Tidal } \\
\text { inundation } \\
(\%)\end{array}$ & $\begin{array}{c}\text { BA } \\
\left(\mathrm{m}^{2} \mathrm{ha}^{-1}\right)\end{array}$ & $\begin{array}{c}\text { DBH } \\
(\mathrm{cm})\end{array}$ & $\begin{array}{c}\text { Density } \\
\left(\text { stem ha }^{-1}\right)\end{array}$ & $\begin{array}{c}\text { AGB } \\
\left(\mathrm{t} \mathrm{DW} \mathrm{ha}^{-1}\right)\end{array}$ & $\begin{array}{c}\text { Canopy } \\
\text { cover }(\eta)\end{array}$ & $\begin{array}{c}\text { LAI } \\
\left(\mathrm{m}^{2} \text { leaf }_{\text {area m }}{ }^{-2}\right. \\
\text { ground } \\
\text { area })\end{array}$ \\
\hline HBA & 28 & 11 & $15 \pm 7$ & $4.8 \pm 2.7$ & $14770 \pm 3214$ & $54.1 \pm 10.2$ & $0.53 \pm 0.1$ & $5.11 \pm 0.9$ \\
HBR & 28 & 20 & $8 \pm 3$ & $7.9 \pm 2.1$ & $3521 \pm 1170$ & $40.5 \pm 8.8$ & $0.66 \pm 0.2$ & $4.86 \pm 1.1$ \\
HBS & 32 & 95 & $39 \pm 7$ & $11.4 \pm 0.5$ & $5191 \pm 345$ & $260.0 \pm 14.1$ & $0.96 \pm 0.1$ & $6.81 \pm 0.7$ \\
AWM & 25 & 95 & $13 \pm 1$ & $14.1 \pm 1.0$ & $1719 \pm 141$ & $60.1 \pm 7.6$ & $0.55 \pm 0.1$ & $4.74 \pm 0.5$ \\
\hline
\end{tabular}

Table 2. Concentrations (\% soil dry weight, mean \pm SE) at the 4 mangrove forests of solid-phase total carbon (TC), total organic carbon (TOC), total nitrogen (TN), total phosphorus (TP), molar C:N:P ratios, total iron (Fe), total manganese (Mn), and total dissolved $\mathrm{H}_{2} \mathrm{~S}$ (in $\mathrm{mM}$ ) in soil sampled in 2006. Values are averages of the entire soil column overlying solid coral

\begin{tabular}{|lrrccrrrrrr}
\hline Stn & \multicolumn{1}{c}{ TC } & \multicolumn{1}{c}{ TOC } & TN & TP & C:N & C:P & N:P & Fe & Mn & H ${ }_{2} \mathrm{C}$ \\
\hline HBA & $3.9 \pm 0.5$ & $3.8 \pm 0.5$ & $0.21 \pm 0.02$ & $0.06 \pm 0.001$ & 21 & 168 & 8 & $5.1 \pm 0.2$ & $0.005 \pm 0.001$ & $0.88 \pm 0.09$ \\
HBR & $16.6 \pm 2.4$ & $15.6 \pm 3.3$ & $0.32 \pm 0.05$ & $0.04 \pm 0.01$ & 56 & 1006 & 18 & $3.3 \pm 0.2$ & $0.03 \pm 0.01$ & $0.68 \pm 0.15$ \\
HBS & $11.0 \pm 0.3$ & $1.7 \pm 0.3$ & $0.07 \pm 0.01$ & $0.03 \pm 0.01$ & 29 & 146 & 5 & $0.5 \pm 0.1$ & $0.006 \pm 0.001$ & $1.15 \pm 0.14$ \\
AWM & $19.9 \pm 1.1$ & $16.9 \pm 2.1$ & $0.43 \pm 0.05$ & $0.07 \pm 0.02$ & 45 & 623 & 14 & $1.2 \pm 0.1$ & $0.03 \pm 0.01$ & $0.59 \pm 0.05$ \\
\hline
\end{tabular}

(DW) $\mathrm{ha}^{-1}$ and the highest LAI, despite occupying a thin $(5$ to $10 \mathrm{~cm}$ ) veneer of unconsolidated carbonate sand above the coral (Table 1). Stn AWM, composed mostly of large $(\mathrm{DBH}=14.1 \mathrm{~cm})$ Sonneratia caseolaris and $S$. lanceolata, was of similar biomass to Stns HBA and HBR, but was a less dense stand with the lowest mean LAI (Table 1).

\section{Edaphic characteristics}

Soils were acidic at Stns HBA, HBR, and AWM, especially below the upper $5 \mathrm{~cm}$, with $\mathrm{pH}$ ranging from $\geq 7.0$ at the surface at Stn HBR to 6.4 at the soil-coral interface at Stn HBS (Fig. 2). Porewater $\mathrm{H}_{2} \mathrm{~S}$ concentrations were highest at Stn HBS, with lower concentrations at Stns HBA, HBR, and AWM (Table 2).

Stns HBR and AWM had the highest soil concentrations of TC, TOC, and TN (Table 2), with no clear trend with soil depth (data not shown). Total P concentrations were higher at Stns AWM and HBA than in the other 2 forests. Total Fe concentrations were highest at Stn HBA, with significantly lower concentrations at Stns HBR, AWM, and HBS. Total Mn concentrations were equivalent at Stns HBR and AWM and significantly less at Stns HBA and HBS; at Stns HBA, HBR, and AWM, concentrations of both metals declined significantly with increasing soil depth (data not shown). At Stns HBA, HBR, and AWM, concentrations of total Ca increased with increasing soil depth (Fig. 3); at Stn HBS, Ca concentrations were 31.1 and $35 \%$ soil
DW at the surface and in the 5 to $10 \mathrm{~cm}$ soil horizon, respectively. On average, site differences in Ca concentrations were: $\mathrm{HBS}>\mathrm{AWM}>\mathrm{HBR}=\mathrm{HBA}$.

\section{Sulfate reduction and net $\mathrm{Fe}$ and $\mathrm{Mn}$ release}

Seasonal differences in rates of sulfate reduction were not significant. In the dry season, differences among sites were: AWM = HBA > HBS > HBR (Table 3). In the wet season, site differences were: AWM $=\mathrm{HBS}>$ HBR = HBA (Table 3 ). The proportion of radiolabel re-

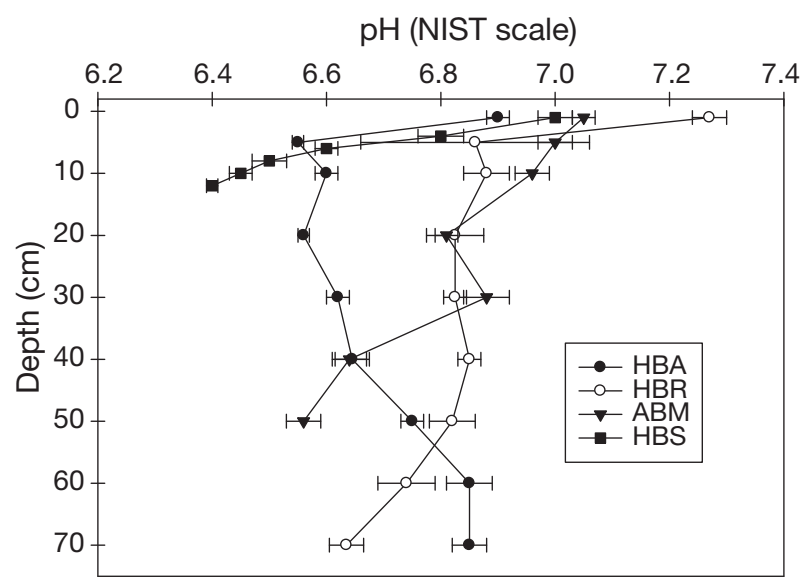

Fig. 2. Vertical profiles of soil $\mathrm{pH}$ to depth of maximum penetration (mean $\pm \mathrm{SE}$ ) at the 4 mangrove forest stations shown in Fig. 1, averaging dry and wet seasons. NIST: National Institute of Standards and Technology 


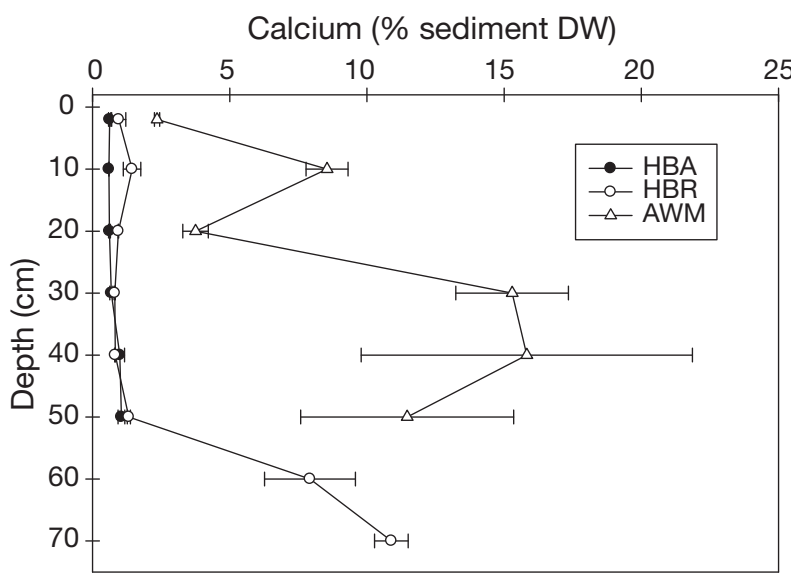

Fig. 3. Vertical profiles of total soil calcium (mean $\pm \mathrm{SE}$ ) at 3 mangrove forest stations, averaging dry and wet seasons

Table 3. Rates of sulfate reduction (SRR, mmol S m $\mathrm{d}^{-1}$, mean $\pm \mathrm{SE}$ ) in soils at the 4 mangrove-reef sites. Values are averages of the entire soil column overlying solid coral. AVS: acid-volatile sulfide

\begin{tabular}{|c|c|c|c|c|c|c|}
\hline \multirow[t]{2}{*}{ Stn } & \multicolumn{3}{|c|}{2006 dry season- -} & \multicolumn{3}{|c|}{2007 wet season -} \\
\hline & Depth $(\mathrm{cm})$ & SRR & $\%$ AVS & Depth $(\mathrm{cm})$ & SRR & $\%$ AVS \\
\hline HBA & 50 & $23.6 \pm 3.7$ & 4 & 50 & $12.8 \pm 2.2$ & 4 \\
\hline HBR & 80 & $12.6 \pm 1.9$ & 6 & 70 & $15.1 \pm 1.8$ & 8 \\
\hline HBS & 12 & $16.4 \pm 1.1$ & 10 & 12 & $28.7 \pm 10.6$ & 30 \\
\hline AWM & 50 & $32.2 \pm 5.5$ & 20 & 30 & $71.3 \pm 43.3$ & 72 \\
\hline
\end{tabular}

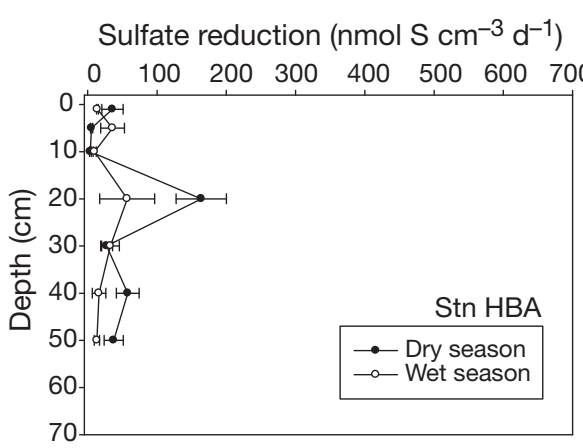

Sulfate reduction ( $\mathrm{nmol} \mathrm{S} \mathrm{cm} \mathrm{cm}^{-3} \mathrm{~d}^{-1}$ )
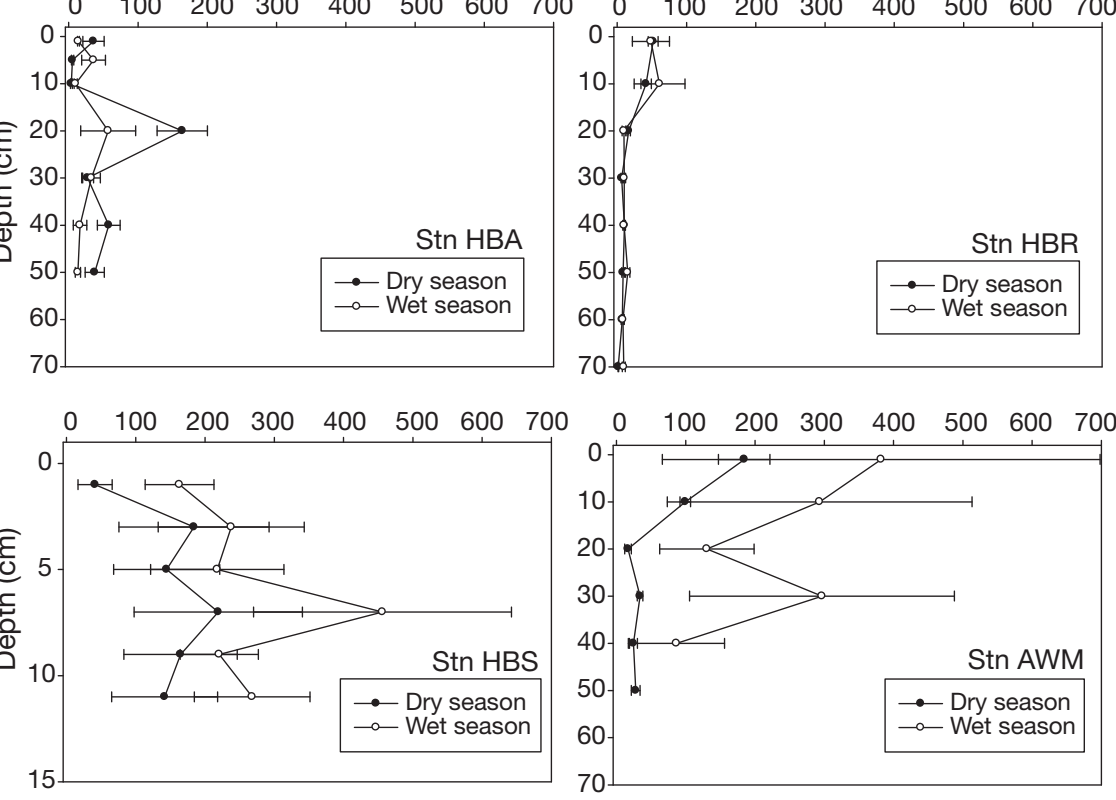

Fig. 4. Vertical profiles of total rates of sulfate reduction (mean $\pm \mathrm{SE}$ ) at the 4 mangrove forests in the 2006 dry and 2007 wet seasons covered in the AVS fraction $\left(\mathrm{H}_{2} \mathrm{~S}, \mathrm{FeS}\right)$ increased among sites in the following order: $\mathrm{HBA}<\mathrm{HBR}<\mathrm{HBS}<$ AWM (Table 3). Rates of sulfate reduction declined significantly with soil depth at Stn HBR (Fig. 4); depth differences were variable at the other 3 sites.

Rates of net Fe and Mn release from incubated soils showed depth-related declines (Fig. 5) at Stns HBA and HBR. There were no measurable rates of metal release in the other 2 forests.

\section{Carbon dioxide and $\mathrm{O}_{2}$ fluxes}

Rates of $\mathrm{CO}_{2}$ release from exposed soils ranged from 22.7 to $154.5 \mathrm{mmol} \mathrm{m}^{-2} \mathrm{~d}^{-1}$, and, from inundated soils, rates were significantly less, ranging from 4.1 to $23.5 \mathrm{mmol} \mathrm{m}^{-2} \mathrm{~d}^{-1}$ (Table 4); seasonal differences among sites were inconsistent. In the dry season, $\mathrm{CO}_{2}$ gas release from exposed soils was highest at Stn AWM, with lower rates at Stns HBA > $\mathrm{HBR}=\mathrm{HBS}$. In the wet season, $\mathrm{CO}_{2}$ gas fluxes from exposed soils were highest at Stn HBA, followed by Stns $\mathrm{AWM}>\mathrm{HBS}=\mathrm{HBR} . \mathrm{CO}_{2}$ release from inundated soils was significantly greater at Stn HBA in the dry season, with lowest fluxes in the wet season at Stn HBS (Table 4).

Rates of $\mathrm{O}_{2}$ consumption from the same exposed soils ranged from 29.4 to $126.9 \mathrm{mmol} \mathrm{m}^{-2} \mathrm{~d}^{-1}$ in the dry season and from 52.4 to $203.4 \mathrm{mmol} \mathrm{m}^{-2}$ $\mathrm{d}^{-1}$ in the wet season (Table 4 ). In the dry season, site differences were: Stns $\mathrm{AWM}>\mathrm{HBA}>\mathrm{HBS}=\mathrm{HBR}$. In the wet season, site differences were: Stns $\mathrm{HBA}>\mathrm{HBR}=\mathrm{AWM}>\mathrm{HBS}$ (Table 4).

Rates of DIC and DO flux were in most cases lower from submerged than from exposed soils, e.g. for $\mathrm{CO}_{2}$ : $\mathrm{HBR}$ (2007) HBS (2006); for $\mathrm{O}_{2}$ : $\mathrm{HBR}$ and HBS (2006) (Table 4). $\mathrm{CO}_{2}$ flux rates from inundated soils in the dry season were lowest at Stn HBA, but increased in the following order: Stns $\mathrm{HBS}>\mathrm{HBR}$ $>$ AWM. In the wet season, $\mathrm{CO}_{2}$ release from submerged soils increased from Stns HBS > HBR > AWM = HBA. Rates of dissolved $\mathrm{O}_{2}$ consumption in submerged soils $\left(\mathrm{O}_{2}\right.$ diss; Table 4$)$ in the dry season did not differ among forests, ranging from 18.5 to $96.7 \mathrm{mmol}$ $\mathrm{O}_{2} \mathrm{~m}^{-2} \mathrm{~d}^{-1}$; wet season differences were Stns HBS $>$ HBR $=$ AWM $>$ HBA. 
Table 4. Rates $\left(\mathrm{mmol} \mathrm{m} \mathrm{m}^{-2} \mathrm{~d}^{-1}\right.$, mean $\pm \mathrm{SE}$ ) of dissolved inorganic carbon (DIC) release from tidally inundated chambers (DIC flux), DIC release from core incubations (DIC core), gaseous $\mathrm{CO}_{2}$ release from air-exposed soil in chambers $\left(\mathrm{CO}_{2}\right.$ gas exposed) and in inundated chambers $\left(\mathrm{CO}_{2}\right.$ gas inundated), gaseous $\mathrm{O}_{2}$ consumption from air-exposed soil in chambers $\left(\mathrm{O}_{2}\right.$ gas exposed), and dissolved $\mathrm{O}_{2}$ flux from tidally inundated soil in darkened chambers $\left(\mathrm{O}_{2}\right.$ diss $)$ at the forest sites

\begin{tabular}{|lcccccc|}
\hline $\begin{array}{c}\text { Stn/ } \\
\text { year }\end{array}$ & $\begin{array}{c}\text { DIC } \\
\text { flux }\end{array}$ & $\begin{array}{c}\text { DIC } \\
\text { core }\end{array}$ & $\begin{array}{c}\mathrm{CO}_{2} \text { gas } \\
\text { exposed }\end{array}$ & $\begin{array}{c}\mathrm{CO}_{2} \text { gas } \\
\text { inundated }\end{array}$ & $\begin{array}{c}\mathrm{O}_{2} \text { gas } \\
\text { exposed }\end{array}$ & $\begin{array}{c}\mathrm{O}_{2} \\
\text { diss }\end{array}$ \\
\hline HBA & & & & & & \\
2006 & $14.3 \pm 4.9$ & $22.1 \pm 3.1$ & $44.3 \pm 4.1$ & $23.5 \pm 0.7$ & $29.4 \pm 24.0$ & $18.5 \pm 10.0$ \\
2007 & $10.4 \pm 8.7$ & $11.4 \pm 16.2$ & $154.5 \pm 27.9$ & $14.3 \pm 4.3$ & $203.4 \pm 18.9$ & $10.4 \pm 2.1$ \\
HBR & & & & & & \\
2006 & $34.4 \pm 1.7$ & $40.1 \pm 8.4$ & $22.7 \pm 9.2$ & $12.7 \pm 2.0$ & $30.9 \pm 16.1$ & $37.5 \pm 14.8$ \\
2007 & $45.0 \pm 5.5$ & $58.4 \pm 9.4$ & $25.6 \pm 6.0$ & $11.9 \pm 0.2$ & $127.7 \pm 41.1$ & $38.5 \pm 3.0$ \\
HBS & & & & & & \\
2006 & $50.1 \pm 5.1$ & $62.3 \pm 7.9$ & $50.8 \pm 6.9$ & $5.6 \pm 0.6$ & $83.4 \pm 13.4$ & $96.7 \pm 16.0$ \\
2007 & $57.2 \pm 4.4$ & $69.3 \pm 8.4$ & $34.6 \pm 18.2$ & $6.7 \pm 1.1$ & $52.4 \pm 7.1$ & $87.7 \pm 6.5$ \\
AWM & & & & & & \\
2006 & $18.4 \pm 3.0$ & $12.7 \pm 6.2$ & $122.0 \pm 28.6$ & $4.1 \pm 0.9$ & $126.9 \pm 24.9$ & $23.4 \pm 17.3$ \\
2007 & $28.7 \pm 1.9$ & $26.5 \pm 3.4$ & $76.1 \pm 18.5$ & $21.2 \pm 7.6$ & $101.7 \pm 30.3$ & $26.3 \pm 4.1$ \\
\hline
\end{tabular}

DIC release from incubated soils (DIC core; Table 4) ranged from 12.7 to $62.3 \mathrm{mmol} \mathrm{m}^{-2} \mathrm{~d}^{-1}$ in the dry season and from 11.4 to $69.3 \mathrm{mmol} \mathrm{m}^{-2} \mathrm{~d}^{-1}$ in the wet season and, in most cases, were not significantly different from flux rates across the soil-water interface (DIC flux; Table 4). There were site differences in 2006: Stns HBS > HBR > HBA > AWM. In the 2007 wet season, site differences were: Stns HBS $=\mathrm{HBR}>$ $\mathrm{AWM}=\mathrm{HBA}$. At all sites, rates of DIC release declined significantly with increasing soil depth (data not shown).
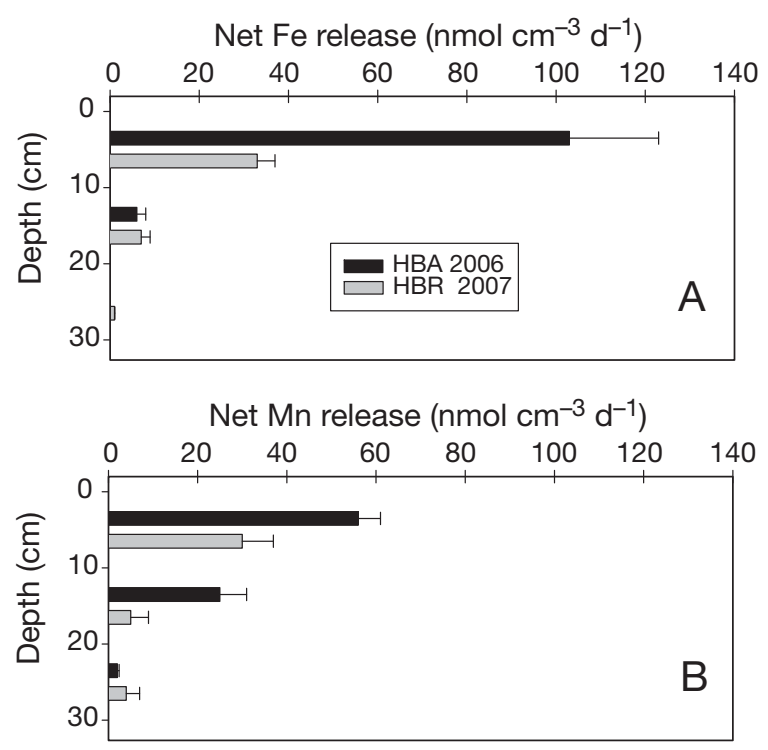

Fig. 5. Vertical profiles of net (A) iron and (B) manganese production (mean $\pm \mathrm{SE}$ ) in the soil at Stns HBA and HBR in the 2006 dry and 2007 wet seasons

\section{Rates of dissolved nutrient, $\mathrm{Ca}$, and $\mathrm{H}_{2} \mathrm{~S}$ flux}

Rates of $\mathrm{NH}_{4}{ }^{+}$and $\mathrm{NO}_{2}^{-}+\mathrm{NO}_{3}^{-}$flux (Table 5) were not significant in the wet season in 3 of the 4 forests, but were measurable at Stn AWM, where, in both seasons, fluxes were out of the soil. Fluxes of $\mathrm{NH}_{4}{ }^{+}, \mathrm{NO}_{2}{ }^{-}+\mathrm{NO}_{3}{ }^{-}$, and $\mathrm{PO}_{4}{ }^{3-}$ at the other sites were into the soil on 9 of 12 occasions (Table 5). $\mathrm{H}_{2} \mathrm{~S}$ efflux was measurable in the dry season only at Stn HBS, but was measurable in all 4 forests in the wet season, with lowest rates at Stn HBR (Table 5). Rates of dissolved Ca flux across the soil-water interface ranged among forest sites from 425 to $2500 \mu \mathrm{mol} \mathrm{m}{ }^{-2}$ $\mathrm{d}^{-1}$, with highest rates at Stn AWM (Table 5).

\section{Methane release}

Rates of $\mathrm{CH}_{4}$ release (Table 6) ranged from 16.4 to $384.4 \mu \mathrm{mol} \mathrm{CH}_{4} \mathrm{~m}^{-2} \mathrm{~d}^{-1}$, with highest mean rates at Stn HBS. In the dry season, site differences were: Stns HBS $=\mathrm{AWM}=\mathrm{HBA}>\mathrm{HBR}$ and, in the wet season, the differences were: Stns HBS $>$ AWM $>$ HBR = HBA.

\section{Nitrogen metabolism}

Rates of net $\mathrm{NH}_{4}{ }^{+}$release (as total nitrogen mineralization; Table 7) over the entire soil column were measured only in the wet season, and were highest at Stn HBS, followed by Stn AWM, with significantly lower rates at Stns HBA and HBR. At Stns HBA and AWM, ammonification rates declined with increasing soil depth. At Stns HBR and AWM, rates either increased with soil depth or showed no clear change (Fig. 6).

Rates of $\mathrm{N}_{2}$ release (Table 6) ranged from 180 to $5588 \mu \mathrm{mol} \mathrm{N} \mathrm{m}^{-2} \mathrm{~d}^{-1}$. In the dry season, rates at Stn HBA were highly variable and not significantly different from those at the other 3 sites, where rates were lowest at Stn HBS. In the wet season, highest rates were measured at Stn AWM; Stn HBS exhibited the lowest rates among the other 3 forests.

Rates of nitrogen fixation were measured only at Stn AWM in 2006. $\mathrm{N}_{2}$ fixation rates were higher rates on Sonneratia pneumatophores than in surface soils in both seasons (Table 6). The soil rates at Stn AWM were significantly higher than rates measured in surface soils at the other 3 forests in 2006. 
Table 5. Rate of dissolved inorganic solute flux $\left(\mu \mathrm{mol} \mathrm{m}{ }^{-2} \mathrm{~d}^{-1}\right.$, mean $\left.\pm \mathrm{SE}\right)$ across the soil-water interface in inundated clear chambers (except where noted) at the 4 mangrove sites. All fluxes were corrected for tidal inundation

\begin{tabular}{|lccccc|}
\hline Stn/year & $\mathrm{NH}_{4}{ }^{+}$ & $\mathrm{NO}_{2}{ }^{-}+\mathrm{NO}_{3}{ }^{-}$ & $\mathrm{PO}_{4}{ }^{3-}$ & $\mathrm{H}_{2} \mathrm{~S}$ & $\mathrm{Ca}$ \\
\hline HBA & & & & & \\
2006 & $-400 \pm 240$ & $300 \pm 75$ & $200 \pm 120$ & 0 & $1550 \pm 375$ \\
2007 & 0 & 0 & $-370 \pm 250$ & $4800 \pm 400$ & $1500 \pm 180$ \\
HBR & & & & & \\
2006 & $-620 \pm 310$ & $65 \pm 130$ & $-20 \pm 10$ & 0 & $500 \pm 175$ \\
2007 & 0 & 0 & $-165 \pm 80$ & $3800 \pm 620$ & $425 \pm 65$ \\
HBS & & & & & \\
2006 & $-700 \pm 185$ & $-10 \pm 20$ & $-25 \pm 110$ & $200 \pm 10$ & $1375 \pm 250$ \\
2007 & 0 & 0 & $-270 \pm 100$ & $5600 \pm 130$ & $1000 \pm 125$ \\
AWM & & & & & \\
2006 & $-200 \pm 30$ & $-40 \pm 5$ & $-20 \pm 5$ & 0 & $2500 \pm 500$ \\
2007 & $-100 \pm 50$ & $-20 \pm 10$ & $-70 \pm 30$ & $6100 \pm 390$ & $2375 \pm 500$ \\
& & & & & \\
\hline
\end{tabular}

construction and other infrastructure development-their decline has not been as severe as for coral reefs due to greater resilience and their ability to readily colonize newly formed soil drapes derived from land erosion (Budiman et al. 1986). Like terrestrial trees breaking up pavement, we observed evidence of mangroves in the process of breaking apart the coral framework by infiltration and growth of shallow roots, including prop roots and pneumatophores.

Dividing the above-ground biomass (Table 1) by the known ages of initial colonization (see 'Materials and methods') gives estimates of biomass accumulation for these forests of 1.9, 1.5, 8.1, and $2.4 \mathrm{t} \mathrm{C} \mathrm{ha}^{-1} \mathrm{yr}^{-1}$ for Stns HBA, HBR, HBS, and AWM. These rates of accumulation are within the range of values obtained for other mangrove forests (Clough

\section{DISCUSSION}

\section{Forest-microbe-soil interrelations}

Mangrove forests are replacing many fringing coral reefs killed by enhanced runoff along stretches of the Sulawesi and Sumatran coasts. An accurate estimate of the areal extent of this change is not available, but large tracts of Indonesia's coastline have succumbed to increased anthropogenic pressures and the loss of a large fraction ( $70 \%$; Tun et al. 2004) of the archipelago's fringing reefs to enhanced sedimentation and nutrient levels. Although mangrove losses continue unabated on some islands - mostly for shrimp pond

Table 6. Rates of methanogenesis $\left(\mu \mathrm{mol} \mathrm{CH}_{4} \mathrm{~m}^{-2} \mathrm{~d}^{-1}\right.$, mean \pm

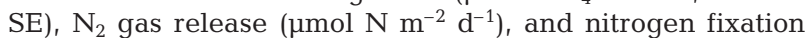
$\left(\mu \mathrm{mol} \mathrm{N} \mathrm{m}^{-2} \mathrm{~d}^{-1}\right.$ ) at the 4 mangrove sites. No $\mathrm{N}_{2} \mathrm{O}$ flux was detected at any site in either year. S: soil; P: Sonneratia pneumatophores; NA: not measured

\begin{tabular}{|c|c|c|c|}
\hline Stn/year & $\begin{array}{l}\text { Methano- } \\
\text { genesis }\end{array}$ & $\begin{array}{l}\mathrm{N}_{2} \text { gas } \\
\text { release }\end{array}$ & $\begin{array}{l}\text { Nitrogen } \\
\text { fixation }\end{array}$ \\
\hline \multicolumn{4}{|l|}{ HBA } \\
\hline 2006 & $103.8 \pm 17.1$ & $5588 \pm 5754$ & NA \\
\hline 2007 & $16.4 \pm 6.4$ & $918 \pm 750$ & $567 \pm 82$ \\
\hline \multicolumn{4}{|l|}{ HBR } \\
\hline 2006 & $20.4 \pm 13.0$ & $1448 \pm 958$ & NA \\
\hline 2007 & $28.0 \pm 9.7$ & $662 \pm 1$ & $97 \pm 48$ \\
\hline \multicolumn{4}{|l|}{ HBS } \\
\hline 2006 & $196.6 \pm 23.5$ & $386 \pm 0$ & NA \\
\hline 2007 & $384.4 \pm 161.7$ & $180 \pm 124$ & $305 \pm 249$ \\
\hline \multicolumn{4}{|l|}{ AWM } \\
\hline 2006 & $136.8 \pm 67.1$ & $3224 \pm 2776$ & $\begin{array}{l}238 \pm 83(\mathrm{~S}) \\
860 \pm 45(\mathrm{P})\end{array}$ \\
\hline 2007 & $34.8 \pm 0.0$ & $3614 \pm 0$ & $\begin{array}{c}1648 \pm 230(\mathrm{~S}) \\
4316 \pm 1772(\mathrm{P})\end{array}$ \\
\hline
\end{tabular}
1998, Komiyama et al. 2008). Comparing these rates of biomass accumulation with rates of soil metabolism (Fig. 7), there are significant exponential relationships of mangrove growth with soil carbon and oxygen metabolism, ammonification, and methane flux. Mangrovemicrobe-soil relationships are usually closely linked, driven by high nutrient and water requirements needed to fuel rapid rates of tree photosynthesis (Alongi 2005). These relationships are exponential because of the high level of growth and mineralization at Stn HBS, which has been receiving aquaculture effluent from the BBL laboratory since the 1970s (see 'Materials and methods: Study sites'). If this forest had remained unpolluted, the forest growth to microbial mineralization statistical relationships may have been linear instead of exponential, but metabolic activities in these soils may, in any case, become limiting either by essential micronutrients, cellular/metabolic constraints, and/or by feedback from physicochemical conditions, such as build up of potentially toxic metabolites. Further constraints may include limitation of gas exchange, for instance, the diffusive exchange of $\mathrm{CO}_{2}$

Table 7. Comparison of mean rates $\left(\mathrm{mmol} \mathrm{m} \mathrm{m}^{-2} \mathrm{~d}^{-1}\right)$ of total nitrogen mineralization (TNM) and molar $\mathrm{C}: \mathrm{N}$ ratios using total carbon mineralization estimated from dissolved inorganic carbon (DIC) fluxes and $\mathrm{O}_{2}$ fluxes (Table 4) measured in 2007 at the 4 mangrove sites

\begin{tabular}{|lccc|}
\hline Stn & TNM & $\begin{array}{c}\text { Mineralized C:N } \\
\text { ratios (using DIC) }\end{array}$ & $\begin{array}{c}\text { Mineralized C:N } \\
\text { ratios (using O }\end{array}$ \\
\hline HBA & $31.1 \pm 4.4$ & 1.5 & 3.4 \\
HBR & $20.3 \pm 2.1$ & 1.7 & 4.1 \\
HBS & $64.2 \pm 4.3$ & 0.7 & 1.1 \\
AWM & $40.2 \pm 3.3$ & 1.0 & 1.6 \\
\hline
\end{tabular}




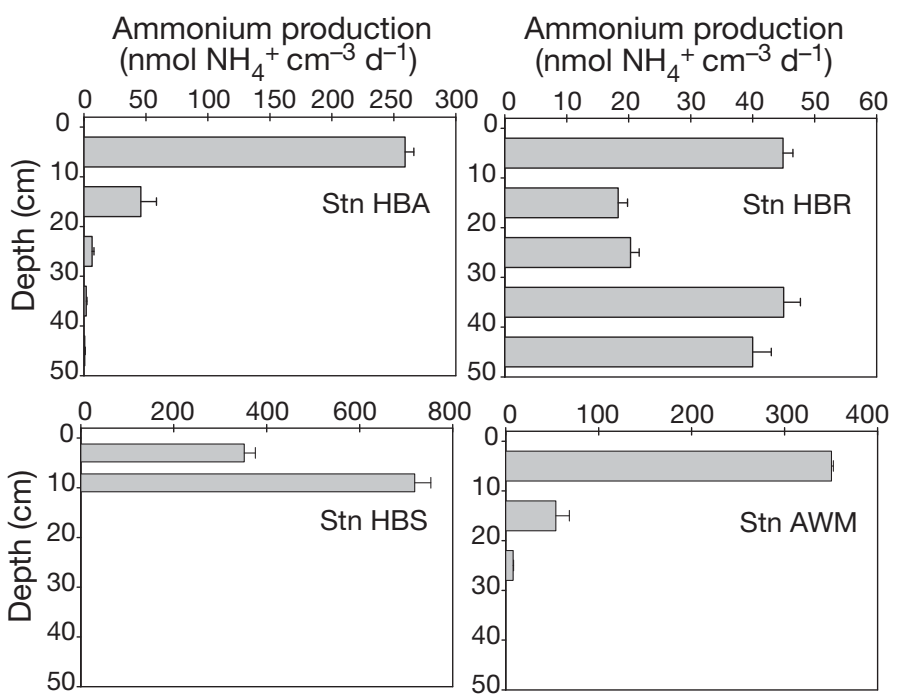

Fig. 6. Vertical profiles of net ammonium production (mean \pm SE) in the soil at the 4 forest stations during the 2007 wet season

being dependent on the $\mathrm{p}_{\mathrm{CO}_{2}}$ gradient across the film of water over the soil surface, which can be diminished under stagnant conditions in the air layer above the soil.

The relationship between mangrove biomass accumulation and soil metabolism is usually not as clear cut, even in correlative analyses (Alongi, 2005), but in these Indonesian forests the relationship may be particularly intense, especially at Stn HBS, where the unconsolidated soil is a thin veneer, restricting the bulk of fine root development (D. Alongi pers. obs.)
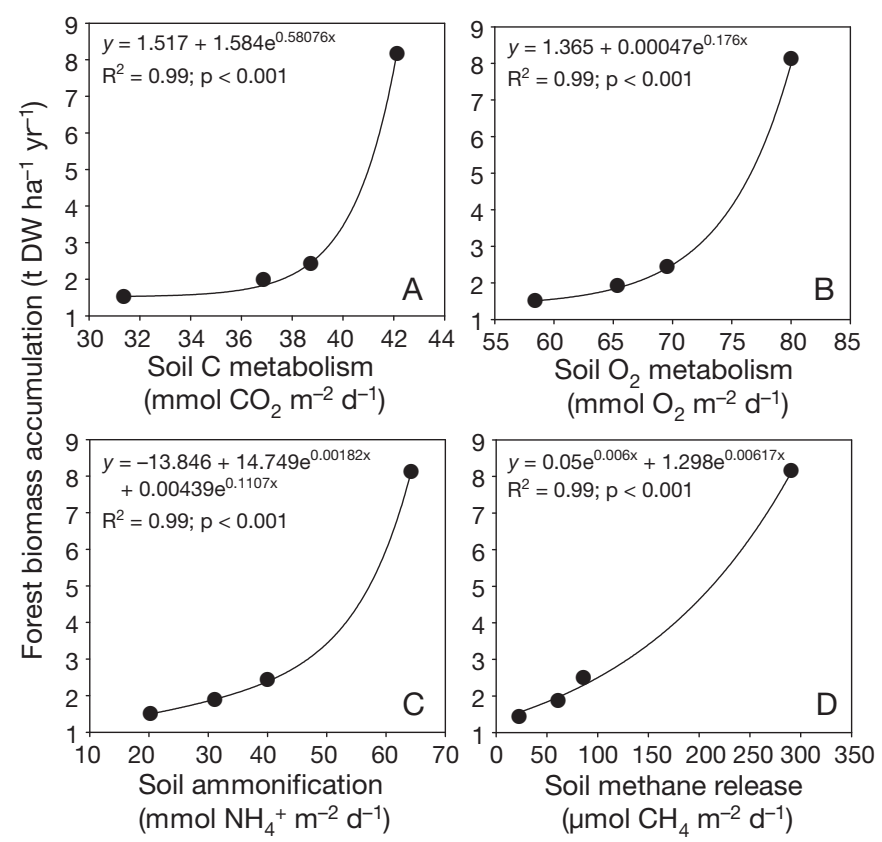

Fig. 7. Relationship between above-ground biomass accumulation and (A) soil C metabolism, (B) soil $\mathrm{O}_{2}$ metabolism, (C) soil ammonification, and (D) methane release in the 4 forests and soil metabolism to the near-surface layers receiving aquaculture effluent. A similar situation exists at Stn AWM, where the soil depth varies spatially, but is often no more than 1 to $2 \mathrm{~cm}$ thick in many areas within the forest. The forests may have also acquired nutrients via roots that have penetrated the coral rock, although this possibility was not explored.

High rates of soil metabolism can fuel high rates of net forest primary productivity $\left(P_{\mathrm{N}}\right)$, and vice versa. Our data show high rates of carbon and nitrogen mineralization compared with rates measured in other mangrove soils, although this may partly reflect the shallow soil depth (Alongi 2005, 2007, Lovelock 2008). Using literature values (Clough \& Sim 1989, Clough 1997 ) of leaf photosynthesis $(A)$ for these species (Stn AWM is excluded as no data are available for Sonneratia spp.) and using the formula $P_{\mathrm{N}}=A \times d \times$ LAI ( $d$ is daylength), we estimated rates of net forest primary production to be $13.3,12.6$, and $17.6 \mathrm{~g} \mathrm{C} \mathrm{m}^{-2} \mathrm{~d}^{-1}$ for Stns HBA, HBR, and HBS, respectively. These values are higher than the global average of $12 \mathrm{~g} \mathrm{C} \mathrm{m}^{-2} \mathrm{~d}^{-1}$ (Alongi 2007). Estimated $\mathrm{N}$ demand, calculated by converting these values to nitrogen using whole-tree $\mathrm{C}: \mathrm{N}$ ratios in Alongi et al. (2003), equated to 31.1, 20.0, and $29.1 \mathrm{mmol} \mathrm{N} \mathrm{m}^{-2} \mathrm{~d}^{-1}$ for Stns HBA, HBR, and HBS, respectively. Comparing these values with the ammonification rates (Table 7 ) and rates of $\mathrm{N}$ solute input from the overlying water (Table 5), sufficient nitrogen was available via microbial $\mathrm{N}$ mineralization to meet forest $\mathrm{N}$ demand. As noted earlier, there was a clear statistical relationship between soil ammonification rates and rates of mangrove biomass accumulation. This is in agreement with earlier $\mathrm{N}$ cycling studies in Australia, Thailand, and Malaysia (Kristensen et al. 2000, Alongi 2005) showing rapid utilization and turnover of the soil ammonium pool and the dominance of tree uptake on the $\mathrm{N}$ cycle.

\section{Impact on dissolution of coral carbonate}

Mangroves, by virtue of their metabolic activities, can stimulate soil microbial activity (Alongi 2005), in turn, fostering carbonate dissolution. Several lines of evidence suggest carbonate dissolution in these Indonesian soils: (1) pH was frequently <7; (2) solidphase calcium concentrations increased with increasing soil depth; (3) concentrations of porewater $\mathrm{H}_{2} \mathrm{~S}$ were high, but concentrations of dissolved iron and manganese were low; and (4) there was significant release of dissolved calcium across the soil-water interface.

The high concentrations of porewater $\mathrm{H}_{2} \mathrm{~S}$, the absence (in most samples) of detectable concentrations of dissolved $\mathrm{Fe}$ and $\mathrm{Mn}$, and acidic soil conditions 
would favor dissolution. With insufficient concentrations of dissolved Fe to precipitate significant amounts of iron sulfide minerals, enough acidity would be generated to dissolve carbonate, as the oxidation of the large amounts of free sulfides produced during sulfate reduction would result in the build up of protons to drive $\mathrm{CaCO}_{3}$ dissolution (Ogrinc et al. 2003). This is in addition to carbonic acid generated by aerobic respiration.

Assuming that all of the dissolved calcium flux was derived from dissolution of coral rubble, minimum estimates of carbonate dissolution can be given as 0.4 to $2.5 \mathrm{mmol} \mathrm{CaCO}_{3} \mathrm{~m}^{-2} \mathrm{~d}^{-1}$. These crude estimates equate to $1,0.6,1.7$, and $3.8 \%$ of total soil metabolism (based on the oxygen fluxes). It appears unlikely that carbonate dissolution contributes greatly to carbon flux in these carbonate-rich deposits.

\section{Microbial $\mathrm{C}$ mineralization rates and pathways}

In marine sediments, $\mathrm{CO}_{2}$ release equates with total carbon mineralization. Total $\mathrm{O}_{2}$ consumption also reflects total mineralization as it encompasses aerobic respiration and indirectly represents anaerobic respiration via oxidation of reduced metabolites produced by anaerobes; this, in itself, further assumes complete (or nearly so) oxidation. This is a valid assumption in most estuarine and marine sediments and appears to be true in these deposits; rates of reduced solute release $\left(\mathrm{NH}_{4}{ }^{+}, \mathrm{Fe}, \mathrm{Mn}\right)$ across the soil-water interface were very low compared with production within the soils. In most wetland soils and coastal sediments, the ratio of $\mathrm{O}_{2}: \mathrm{CO}_{2}$ is very close to model Redfield organic matter, which yields a respiration coefficient for complete oxidation of 1.3 (Middelburg et al. 2005). In these Indonesian deposits, the ratio of $\mathrm{O}_{2}: \mathrm{CO}_{2}$ ranged widely from 0.5 to 5.0, suggesting that organic matter mineralized in these soils was probably derived from a variety of sources, in addition to mangrove material. This idea is realistic, as algal matter may be transported from adjacent reefs in the Bay of Lampung and there is a high volume of aquaculture effluent entering the northern end of Hurun Bay. In addition, the rates of $\mathrm{CO}_{2}$ and $\mathrm{O}_{2}$ fluxes correlated positively $\left(\mathrm{R}^{2}=0.85\right.$; $\mathrm{p}<0.001$ ). Thus, there was no indication that rates of $\mathrm{CO}_{2}$ flow were noticeably enhanced by carbonate dissolution.

Some rates of $\mathrm{CO}_{2}$ flux were low compared with rates of $\mathrm{O}_{2}$ consumption, but such discrepancies were likely the result of experimental artifacts, especially, a possible lack of steady-state conditions during flux chamber and core incubations. It is also possible that some DIC was lost from the soils via horizontal transport. Subsurface water was often seen running out of the soil bed at low tide. Sulfate reduction accounted for 38 to $186 \%$ (mean $=120 \%$ ) of total carbon mineralization, so it is likely that some $\mathrm{CO}_{2}$ produced by sulfate reducers was lost. This is supported by the fact that other metabolic pathways likely account for some proportion of total carbon mineralization. For example, although methane release was a minor pathway, there was some evidence of iron and manganese reduction in addition to some probable aerobic respiration in the upper few millimeters of soil. Drainage loss of DIC-rich porewater has been observed in other mangrove ecosystems (Alongi 2001, Bouillon et al. 2008).

The rates of other processes must similarly be treated with caution as most were derived from flux chamber measurements and core incubations, both of which are unlikely to reflect in situ conditions. For instance, DIC fluxes were measured from dark chambers, which would only represent mineralization, whereas fluxes of $\mathrm{NH}_{4}{ }^{+}$and $\mathrm{NO}_{2}^{-}+\mathrm{NO}_{3}^{-}$were measured from clear chambers, which would represent both autotrophic and heterotrophic conditions. The core incubations may not reflect in situ rates, because, over the incubation times of several days, natural conditions such as tidal inundation and redox conditions were not maintained; further, some elements were likely to be depleted during the end-point incubations.

Rates of methane release are problematic, as emissions across the soil-air interface do not reflect rates of methanogenesis within mangrove deposits; most $\mathrm{CH}_{4}$ diffusing toward the soil surface may be consumed by prokaryotic methanotrophs. Aerobic oxidation of $\mathrm{CH}_{4}$ is often enhanced in near-surface soils by clay minerals (Abril et al. 2007). Rates of methane release from these forest soils were at the high end of the range of rates obtained in other mangrove forests (Biswas et al. 2007, Upstill-Goddard et al. 2007, Kristensen et al. 2008).

\section{Nitrogen cycling and greenhouse gas emissions}

The rates of many of the individual $\mathrm{N}$ processes were rapid, fuelling net forest primary productivity as noted earlier for ammonification, compared with rates measured in other forests. The rapid rates of $\mathrm{N}$ metabolism resulted in low C:N mineralization ratios (Table 7). This is partly an artefact of probable transport losses of carbon, but the low $\mathrm{C}: \mathrm{N}$ ratios do suggest decomposition of high-quality organic matter, such as algae. At all sites we observed macroalgal matter on coral rubble and patchy mats of microalgae on the soil surface. At all 4 sites, rates of dissolved inorganic nutrient flux were nearly always into the soil, implying utilization of tidal water nutrients by surface algae. Also, there was some nitrogen fixation measured in the wet season, and at Stn AWM, some indication that algae 
and microflora on the Sonneratia pneumatophores were also fixing nitrogen, suggesting that nitrogen fixation was occurring on above-ground structures.

Although there was no release of $\mathrm{N}_{2} \mathrm{O}$, rates of denitrification ranged from 180 to $5588 \mu \mathrm{mol} \mathrm{N} \mathrm{m}^{-2} \mathrm{~d}^{-1}$ (Table 6). These denitrification rates are high compared with rates measured in other mangrove forests (Nedwell et al. 1994, Rivera-Monroy \& Twilley 1996, Kristensen et al. 1998, 2000) despite high porewater concentrations of $\mathrm{H}_{2} \mathrm{~S}$, which can inhibit denitrifying activity. However, these $\mathrm{N}_{2}$ losses may include an unknown amount of ammonium oxidation linked to nitrate reduction (Thamdrup \& Dalsgaard 2002). We did not measure nitrification, but the rapid rates of ammonification - even if the vast bulk of the produced ammonium was taken up by tree roots - indicate sufficient $\mathrm{NH}_{4}{ }^{+}$to support transformation and utilization by denitrifying and ammonium-oxidizing bacteria.

Overall, rates of greenhouse gas fluxes were low compared with those in other mangrove and wetland soils (Alongi 2007, Bianchi 2007). The molar ratio of $\mathrm{C}$ and $\mathrm{N}$ gas emissions varied greatly (Fig. 8) from 3.1 to 151.4, with an overall mean of 35, comparing favorably with the overall mean $\mathrm{C}: \mathrm{N}$ ratio in the soils of 38 (Table 2). This may be coincidental, but the higher ratios in the wet season (mean $=59.5$ ) compared with low season ratios (mean $=10.5$ ) partly reflect the fact that heavy rainfall may have inhibited $\mathrm{N}_{2}$ gas emissions, especially in the Hurun Bay forests, where wet season rainfall was particularly intense. A thin film of rainwater at the soil surface would slow diffusive transport of gases and increase the level of anoxia (i.e. increased $\mathrm{H}_{2} \mathrm{~S}$ ) compared with soils in the dry season. Lower salinity also plays a direct role in slowing rates of denitrification in mangroves (Alongi 2005).

These gas ratios were much higher than the C:N of mineralization (Table 7), suggesting that despite high

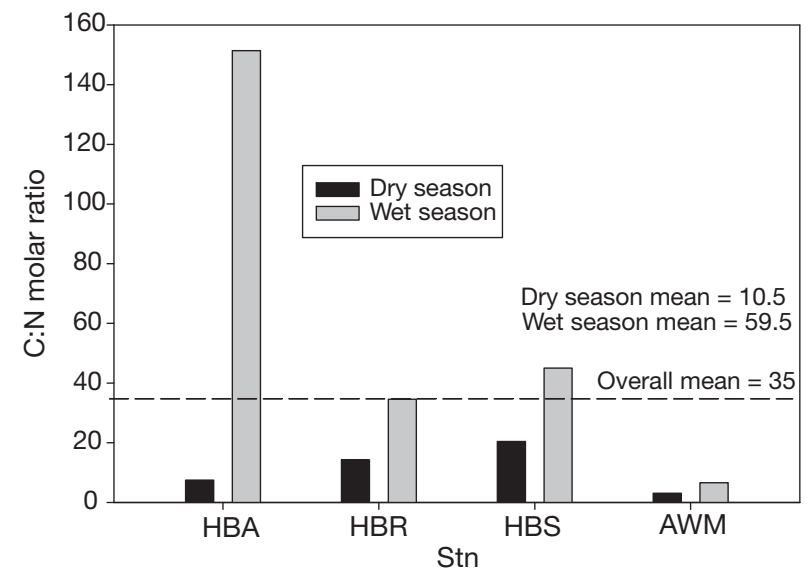

Fig. 8. Stoichiometry of carbon and nitrogen gas emissions from the 4 mangrove forest stations, dry and wet seasons. Values are means of gas fluxes from both exposed and inundated soils rates of microbial mineralization and mangrove production and utilization, environmental factors such as rainfall operate synergistically with natural forest mechanisms to ameliorate emission of nitrogen. The patterns of gas stoichiometry imply that the $\mathrm{N}$ debt needs to be offset by nitrogen fixation, especially where the ratios are lowest, such as at Stn AWM (Fig. 8). The rates of nitrogen fixation in these forests were at the high end of the range of values measured in other mangroves (Lee \& Joye 2006), and, in fact, the highest values we measured were at Stn AWM. Such a balance between sources and sinks conserves nutrients and other elements that may be limiting to these Indonesian mangroves.

The significance of the change from fringing reefs to mangroves along parts of the Indonesian coast may be immense, depending on the areal extent of the problem. In areas where enhanced erosion and subsequent sedimentation in the coastal zone is transforming the coast, there has been a clear shift in water clarity and quality, and in the structure of pelagic and benthic communities from reef-dominated to coastal and estuarine biota (Dr. Sudjiharno, BBL, Lampung, pers. comm.). As we document here, there is a clear change from what was once reef-type biogeochemical cycles to more intense, mangrove- and seagrass-dominated, nutrient cycles and plant growth.

Acknowledgements. We thank Dr. Sudjiharno and Mr. Udin at Balai Bududaya Laut, Lampung, for their immense help and support and the staff at the Research Institute for Coastal Aquaculture in Maros for their valuable help. The late Dr. Taufik Ahmed helped greatly with the work in Awarange Bay. This work was supported by A.C.I.A.R. Grant No. FIS/ 2003/027. We thank B. Smith, A.C.I.A.R. Fisheries Program manager, for his ongoing support.

\section{LITERATURE CITED}

Abril G, Commarieu MV, Guerin F (2007) Enhanced methane oxidation in an estuarine turbidity maximum. Limnol Oceanogr 52:470-475

Alongi DM (2001) The influence of mangrove production and biomass on biogeochemical processes in tropical macrotidal settings. In: Aller JY, Woodin SA, Aller RC (eds) Organism-sediment interactions. University of South Carolina Press, Columbia, SC, p 223-241

Alongi DM (2005) Mangrove-microbe-soil relations. In: Kristensen E, Haese RR, Kostka JE (eds) Interactions between macro- and microorganisms in marine sediments. American Geophysical Union, Washington, DC, p 85-103

Alongi DM (2007) The contribution of mangrove ecosystems to global carbon cycling and greenhouse gas emissions. In: Tateda Y (ed) Greenhouse gas and carbon balances in mangrove coastal ecosystems. Gendai Tosho, Kanagawa, p 1-20

Alongi DM (2008) Mangrove forests: resilience, protection from tsunamis, and responses to global climate change. Estuar Coast Shelf Sci 76:1-13 
Alongi DM, Clough BF, Dixon P, Tirendi F (2003) Nutrient partitioning and storage in arid-zone forests of the mangroves Rhizophora stylosa and Avicennia marina. Trees (Berl) 17:51-60

Alongi DM, Pfitzner J, Trott LA (2006) Deposition and cycling of carbon and nitrogen in carbonate mud of the lagoons of Arlington and Sudbury Reefs, Great Barrier Reef. Coral Reefs 25:123-143

Alongi DM, Trott LA, Undu MC, Tirendi F (2008) Benthic microbial metabolism in seagrass meadows along a carbonate gradient in Sulawesi, Indonesia. Aquat Microb Ecol 51:141-152

Bianchi TS (2007) Biogeochemistry of estuaries. Oxford University Press, New York

Bird E (2008) Coastal geomorphology: an introduction, 2nd edn. Wiley, New York

Biswas H, Mukhopadhyay SK, Sen S, Jana TK (2007) Spatial and temporal patterns of methane dynamics in the tropical mangrove dominated estuary, NE coast of Bay of Bengal, India. J Mar Syst 68:55-64

Bouillon S, Borges AV, Casteñeda-Moya E, Diele K and others (2008) Mangrove production and carbon sinks: a revision of global budget estimates. Global Biogeochem Cycles 22:GB2013

Budiman A, Kartawinata K, Prawiroatmodjo S, Sapulete D (1986) Coral reef-associated mangrove communities in Indonesia. In: Soemodihardjo S (ed) Proceedings of MABCOMAR regional workshop on coral reef ecosystems: their management practices and research/training needs. UNESCO, Jakarta, p 12-119

Capone DG (1993) Determination of nitrogenase activity in aquatic samples using the acetylene reduction procedure. In: Kemp PF, Sherr BF, Sherr EB, Cole JJ (eds) Aquatic microbial ecology. Lewis Publishers, Boca Raton, FL, p 621-632

Chuan GK (2005) The climate of southeast Asia. In: Gupta A (ed) The physical geography of southeast Asia. Oxford University Press, Oxford, p 80-93

Cintron G, Novelli YS (1984) Methods for studying mangrove structure. In: Snedaker, SC, Snedaker JG (eds) The mangrove ecosystem: research methods. UNESCO, Paris, p 91-113

Clough BF (1997) Mangrove ecosystems. In: English S, Wilkinson C, Baker V (eds) Survey manual for tropical marine resources, 2nd edn. Australian Institute of Marine Science, Townsville, p 119-196

Clough BF (1998) Mangrove forest productivity and biomass accumulation in Hinchinbrook Channel, Australia. Mangroves Salt Marshes 2:191-198

Clough BF, Scott K (1989) Allometric relationships for estimating above-ground biomass in six mangrove species. For Ecol Manag 27:117-127

Clough BF, Sim RG (1989) Changes in gas exchange characteristics and water-use efficiency of mangroves in response to salinity and vapour pressure deficit. Oecologia 79:38-44

Clough BF, Dixon P, Dalhaus O (1997) Allometric relationships for estimating biomass in multi-stemmed mangrove trees. Aust J Bot 45:1023-1031

Day RW, Quinn GP (1989) Comparisons of treatments after an analysis of variance in ecology. Ecol Monogr 59:433-463

FAO (Food and Agricultural Organization) (2003) Status and trends in mangrove area extent worldwide. Forest Resources Assessment Working Paper 63. FAO, Rome. Available at: http://fao.org/docrep/007/j1533e/J1533E00.htm

> Fossing HR, Jorgensen BB (1989) Measurement of bacterial sulfate reduction in sediments: evaluation of a single-step chromium reduction method. Biogeochemistry 8:205-222

Hall POJ, Aller RC (1992) Rapid, small-volume flow injection analysis for $\Sigma \mathrm{CO}_{2}$ and $\mathrm{NH}_{4}{ }^{+}$in marine and freshwaters. Limnol Oceanogr 37:1113-1118

Komiyama A, Ong JE, Sasitorn P (2008) Allometry, biomass, and productivity of mangrove forests: a review. Aquat Bot 89:128-137

Kristensen E, Jensen MH, Banta GT, Hansen K, Holmer M, King GM (1998) Transformation and transport of inorganic nitrogen in sediments of a southeast Asian mangrove forest. Aquat Microb Ecol 15:165-175

Kristensen E, Andersen FO, Holboe N, Holmer M, Thongham N (2000) Carbon and nitrogen mineralization in sediments of the Bangrong mangrove area, Phuket, Thailand. Aquat Microb Ecol 22:199-213

Kristensen E, Bouillon S, Dittmar T, Marchand C (2008) Organic carbon dynamics in mangrove ecosystems: a review. Aquat Bot 89:201-219

Lee RY, Joye SB (2006) Seasonal patterns of nitrogen fixation and denitrification in oceanic mangrove habitats. Mar Ecol Prog Ser 307:127-141

Loring DH, Rantala RTT (1992) Manual for the geochemical analyses of marine sediments and suspended particulate matter. Earth Sci Rev 32:235-283

Lovelock CE (2008) Soil respiration and belowground carbon allocation in mangrove forests. Ecosystems 11:342-354

Lustwerk RL, Burdige DJ (1995) Elimination of dissolved sulfide interference in the flow injection determination of $\Sigma \mathrm{CO}_{2}$ by addition of molydate. Limnol Oceanogr 40 : $1011-1012$

Middelburg JJ, Duarte CM, Gattuso JP (2005) Respiration in coastal benthic communities. In: del Giorgio PA, Williams PJ leB (eds) Respiration in aquatic ecosystems. Oxford University Press, Oxford, p 206-224

Mimura N (2006) State of the environment in the Asia and Pacific coastal zones and effects of global change. In: Harvey $\mathrm{N}$ (ed) Global change and integrated coastal management. Springer, Dordrecht, p 17-38

Nedwell DB, Blackburn TH, Wiebe WJ (1994) Dynamic nature of the turnover of organic carbon, nitrogen and sulfur in the sediments of a Jamaican mangrove forest. Mar Ecol Prog Ser 110:223-231

Nontji A (2000) Coral reefs of Indonesia: past, present and future. In: Proc 9th Int Coral Reef Symp, Vol 1. International Coral Reef Society, Bali, p 17-27

- Nowicki BL (1994) The effect of temperature, oxygen, salinity, and nutrient enrichment on estuarine denitrification rates measured with a modified nitrogen gas flux technique. Estuar Coast Shelf Sci 38:137-156

Ogrinc N, Faganelli J, Pezdic J (2003) Determination of organic carbon remineralization in near-shore marine sediments (Gulf of Trieste, northern Adriatic) using stable carbon isotopes. Org Geochem 34:681-692

Rice RC (1991) Environmental degradation, pollution, and the exploitation of Indonesia's fishery resources. In: Hardjono J (ed) Indonesia: resources, ecology, and environment. Oxford University Press, Singapore, p 154-176

Rivera-Monroy VH, Twilley RR (1996) The relative role of denitrification and immobilization in the fate of inorganic nitrogen in mangrove sediments (Terminos Lagoon, Mexico). Limnol Oceanogr 41:284-296

Ryle VD, Wellington JT (1982) Reduction column for automated determination of nitrates. Analytical Laboratory Note, No. 19. Australian Institute of Marine Science, Townsville

Ryle VD, Mueller HR, Gentien P (1981) Automated analysis of nutrients in tropical seawater. Monograph OS-81-4, 
Australian Institute of Marine Science, Townsville

Sekiguchi H, Aksornkoae S (2008) Environment problems in the coastal zone. In: Mimura N (ed) Asia-Pacific coasts and their management: states of environment. Springer, Dordrecht, p 65-171

Sokal RR, Rohlf FJ (1995) Biometry, 3rd edn. Freeman, New York

Thamdrup B, Dalsgaard T (2002) Production of $\mathrm{N}_{2}$ through anaerobic ammonium oxidation coupled to nitrate reduction in marine sediments. Appl Environ Microbiol 68: $1312-1318$

Tomascik T, Mah AJ, Nontji A, Moosa MK (1997) The ecology of Indonesian seas. The ecology of Indonesia series, Vols 7 \& 8. Periplus, Singapore

Tun K, Chou LM, Cabanban A, Tuan VS and others (2004) Status of coral reefs, coral reef monitoring and management in Southeast Asia. In: Wilkinson C (ed) Status of coral reefs of the world: 2004, Vol 1. Australian Institute of

Editorial responsibility: Hans Heinrich Janssen, Oldendorf/Luhe, Germany
Marine Science, Townsville, p 235-275

Upstill-Goddard RC, Barnes J, Ramesh R (2007) Are mangroves a source or a sink for greenhouse gases? In: Tateda Y (ed) Greenhouse gas and carbon balances in mangrove coastal ecosystems. Gendai Tosho, Kanagawa, p 127-138

Whitten T, Henderson GS, Mustafa M (1987) The ecology of Sulawesi. The ecology of Indonesia series, Vol 4. Periplus, Singapore

Whitten T, Damanik SJ, Anwar J, Hisyam N (2000) The ecology of Sumatra. The ecology of Indonesia series, Vol 1. Periplus, Singapore

Woodroffe CD (2002) Coasts: form, process and evolution. Cambridge University Press, Cambridge

Yulianto E, Sukapti WS, Rahardjo AT, Noeradi D, Siregar DA, Suparan P, Hirakawa K (2004) Mangrove shoreline responses to Holocene environmental change, Makassar Strait, Indonesia. Rev Palaeobot Palynol 131:251-268

Submitted: February 20, 2008; Accepted: July 23, 2008

Proofs received from author(s): October 21, 2008 